\title{
Heredo-Familial Expression of Ametropia among Siblings of a Nigerian Family
}

\author{
Emmanuel Olu Megbelayin1,2, Sylvia Iquo-Abasi Akpan1,2 \\ ${ }^{1}$ Department of Ophthalmology, University of Uyo Teaching Hospital, Uyo, Nigeria \\ ${ }^{2}$ Faculty of Clinical Sciences, University of Uyo, Uyo, Nigeria \\ Email: favouredolu@yahoo.com
}

How to cite this paper: Megbelayin, E.O. and Akpan, S.I.-A. (2016) Heredo-Familial Expression of Ametropia among Siblings of a Nigerian Family. Open Journal of Genetics, 6, 74-78.

http://dx.doi.org/10.4236/ojgen.2016.64008

Received: May 20, 2016

Accepted: October 28, 2016

Published: October 31, 2016

Copyright $\odot 2016$ by authors and Scientific Research Publishing Inc. This work is licensed under the Creative Commons Attribution International License (CC BY 4.0).

http://creativecommons.org/licenses/by/4.0/

\begin{abstract}
A case series of 4 siblings who had auto-refraction and subjective refraction, refinement was with 0.25 Jackson Cross Cylinder. Presenting complaint was either blurring of distant vision or missing eye glasses. The eldest sibling started using eye glasses at 15 years of age while the other siblings commenced much earlier. Presenting visual acuities in 7 eyes ranged from 6/9 to 6/18, one eye of the eldest sibling had visual acuity of 6/36. Spherical errors had gender bias with the males more likely to be hypermetropic and the females more likely to be myopic. However, cylinder powers and axes were closely related in all siblings. It was concluded that heredo-familial traits could partly account for some of the striking similarities noted in the outcomes of refraction among the siblings.
\end{abstract}

\section{Keywords}

Heredofamilial, Siblings, Ametropia

\section{Introduction}

Many studies have corroborated the familial and heritability of refractive state of the eye [1] [2] [3]. The chief contributors to ocular refraction and dioptric power are cornea, lens, anterior chamber depth and axial length. Biio et al. [4] in 2005 reported that estimates of heritability for axial length range from $40 \%$ - 94\% and anterior chamber depth from $70 \%$ - 94\% with linkage to chromosomes 2p24 and 1P32.2 respectively. Heritability estimates for corneal curvature, in the same study, was $60 \%-92 \%$ with linkage to chromosomes 2p25, 3P26 and 7q22. Lyhne et al. [5] in an earlier study in 2001 among twins aged 20 - 45 years reported 90\% - 93\% heritability for crystalline lens thickness. Different modes of Mendelian inheritance are associated with refractive errors including autosomal dominant (AD) and sex-linked (X-linked). Loci for autosomal do- 
minant high myopia are located on chromosomes Xq28 18p11.31 2q37, Xq23-25 and 4q.

To date, almost $100 \%$ of identified loci for non-syndromic high myopia are either $\mathrm{AD}$ or X-linked with high penetrance [6]. In a dizygotic twin study, Hammond et al. [2] found that Paired box gene 6 (PAX 6) is strongly linked with refractive errors. Myopia has the strongest evidence for genetic susceptibility, although studies have shown different loci between juvenile-onset myopia (low to moderate myopia) and high myopia. Conversely, hypermetropia and astigmatism have weaker and less consistent linkage with inheritance [7] [8].

In the current report, we undertook a classic comparative study to assess similarities and differences in the outcomes of refraction among 4 siblings of an African family.

\section{History}

Four siblings from a monogamous setting presented on the same clinic day with history of either missing or broken eye glasses. The youngest of the sibling was 9 years old while others were 14, 18, 21 years old. The first two siblings were males while the last two were females. The onsets of eye glasses use were $6,13,12,15$ years from the youngest to the eldest sibling respectively, inability to see distant objects being the reason for their use. Both parents use glasses for sight and reading. Other parts of the history were not contributory.

Clinical examination revealed normal anterior and posterior segments. Auto refraction was carried out with POTEK CO., LTD, (PRK) 2000, Korea followed by a subjective refraction. Axis was refined with Jackson Cross Cylinder ( -0.25 type). The outcomes of refraction were satisfactory precluding the need for cycloplegic refraction.

\section{Results}

There were 4 siblings, 2 males and 2 females. Presenting visual acuities (VA) are shown in Table 1. VA improved to $6 / 6$ in both eyes in all siblings after refraction except the last sibling who had a VA of 6/9 (OU). Details of the refraction of the patients are shown in Table 2.

\section{Discussion}

In our practice, it is an uncommon occurrence for 4 siblings to present on the same clinic day for a non-infectious ocular condition like epidemic haemorrhagic conjunctivitis. This occasion was rare and the striking outcomes of refractions were easily noticed. Studies on refractive errors are common in our clime; however, analytical studies of cases series are sparse. Studies in support of genetics as one of the risk factors of refractive errors have focused on molecular theories [2] [4]. The strength of the current study is the comparative analysis involved in which refraction results of first degree relatives are juxtaposed to allow for logical inferences.

Presenting VA in the siblings ranged from $6 / 9^{+1}$ to $6 / 36$. Except for the eldest, there was clustering of presenting vision between $6 / 9$ and $6 / 18$. This falls within a normal range according to World Health Organization [WHO] classification while the 6/36 
Table 1. Presenting visual acuity.

\begin{tabular}{ccc}
\hline & \multicolumn{2}{c}{ Visual acuity } \\
\cline { 2 - 3 } Sibling & OD & OS \\
\hline 1 & $6 / 9^{+1}$ & $6 / 12$ \\
2 & $6 / 12$ & $6 / 12$ \\
3 & $6 / 12$ & $6 / 18^{+2}$ \\
4 & $6 / 36$ & $6 / 18$ \\
\hline
\end{tabular}

Table 2. Analysis of refraction results in all siblings.

\begin{tabular}{|c|c|c|c|c|c|c|c|c|c|c|c|c|}
\hline \multirow{3}{*}{ Sibling } & \multirow{3}{*}{$\begin{array}{c}\text { Age } \\
\text { (years) }\end{array}$} & \multirow{3}{*}{ Sex } & \multicolumn{10}{|c|}{ Post-refraction } \\
\hline & & & \multicolumn{2}{|c|}{ Spheres } & \multicolumn{2}{|c|}{ Cylinders } & \multicolumn{2}{|c|}{ Axes } & \multicolumn{2}{|c|}{$\begin{array}{l}\text { Spherical } \\
\text { equivalents }\end{array}$} & \multicolumn{2}{|c|}{$\begin{array}{l}\text { Astigmatism } \\
\text { type }\end{array}$} \\
\hline & & & OD & OS & OD & OS & $\mathrm{OD}$ & OS & OD & OS & OD & OS \\
\hline 1 & 9 & Male & +0.50 & +0.50 & -3.00 & -3.50 & 30 & 160 & -1.00 & -1.25 & $\begin{array}{l}\text { With the } \\
\text { rule }\end{array}$ & $\begin{array}{l}\text { With the } \\
\text { rule }\end{array}$ \\
\hline 2 & 14 & Male & 0.00 & 0.00 & -2.00 & -2.00 & 180 & 180 & -1.00 & -1.00 & $\begin{array}{l}\text { With the } \\
\text { rule }\end{array}$ & $\begin{array}{c}\text { With the } \\
\text { rule }\end{array}$ \\
\hline 3 & 18 & Female & -2.50 & -3.00 & -2.00 & -2.50 & 180 & 180 & -3.50 & -4.25 & $\begin{array}{l}\text { With the } \\
\text { rule }\end{array}$ & $\begin{array}{l}\text { With the } \\
\text { rule }\end{array}$ \\
\hline 4 & 21 & Female & -3.50 & -2.00 & -3.00 & -2.50 & 20 & 170 & -5.00 & -3.25 & $\begin{array}{l}\text { With the } \\
\text { rule }\end{array}$ & $\begin{array}{l}\text { With the } \\
\text { rule }\end{array}$ \\
\hline
\end{tabular}

presenting VA in the right eye of the eldest patient is considered to be a form of visual impairment. This can be attributable, at least in part, to a delay in use of glasses until 15 years. Stimulus deprivation amblyopia is a likely outcome of an eye deprived of quality retinal images over a prolonged period as the brain has learnt to cope with blurred images.

Gender as a determinant of refractive status has not been firmly established in available epidemiological studies. In a study in Szczecin, Poland among school children aged 6 - 18 years, Czepita et al. [9] reported that myopia occurred more frequently in girls (7.4\%) than in boys $(5.1 \%)-\mathrm{p}<0.001$. Hyperopia occurred more frequently in boys $(19.6 \%)$ than in girls $(18.2 \%)-\mathrm{p}<0.001$. A slightly higher prevalence of astigmatism in girls $(1.9 \%)$ than in boys $(1.5 \%)$ was also observed $(\mathrm{p}>0.05)$. In that study, whereas spherical errors reached statistical significance, cylindrical error was not statistically significant. This outlook is similar to the findings in the current study where the males have a close range spherical error; plano to +0.50 . On the other hand, the females share common myopic characteristics. This presents a bipolar spectrum where males lie on the hypermetropic end and females on the myopic end. Similar to the finding by Czepita et al., these siblings have cylindrical errors that had no gender bias.

There is the possibility that the non-gender disposition of astigmatism in these siblings may have been decided by inheritance as all astigmatic powers clustered around -2.00 and -3.50 and the axes in all hovered around 180 degrees. Additionally, all had 
with-the-rule astigmatism. In a twin study, Hammond et al. [1] reported dominant genetic effects accounting for between $42 \%$ and $61 \%$ of the variance of astigmatism. In another twin study, Dirani et al. [10] reported a similar proportion of the variance (50\%) of dominant genetic effects in astigmatism. Although, research on the genetics of astigmatism is limited, these studies [1] [11] [12] and the current observation among siblings suggest that dominant genes may be linked with astigmatism.

With spherical equivalents that ranged from -1.00 to -5.00 , all the siblings were myopic. This agrees with previous studies [13] [14] that myopia has a strong genetic mode of inheritance. To date, several genetic loci for non-syndromic myopia have been mapped, including 12 loci linked to high myopia. Moreover, two recent independent genome-wide association studies involving large cohorts of refractive error patients identified loci at chromosome 15q14 and 15q25 [15] [16] [17].

From the observation of refraction outcomes of the siblings under study, it is concluded that genetics continues to play significant role in emmetropization much as previously established environmental factors like near-work and urbanization [18] [19]. It is hoped that further studies would expand the scope of the current study to accommodate more families.

\section{References}

[1] Hammond, C.J., Snieder, H., Gilbert, C.E. and Spector, T.D. (2001) Genes and Environment in Refractive Error: The Twin Eye Study. Investigative Ophthalmology \& Visual Science, 42, 1232-1236.

[2] Hammond, C.J., Andrew, T., Mak, Y.T. and Spector, T.D. (2004) A Susceptibility Locus for Myopia in the Normal Population Is Linked to the PAX6 Gene Region on Chromosome 11: A Genome Wide of Dizygotic Twins. American Journal of Human Genetics, 75, 294-304. http://dx.doi.org/10.1086/423148

[3] Shailaja, V., Minkovitz, J.B., Koray, B., Lydia, R., et al. (1999) Comparative Corneal Topography and Refractive Variables in Monozygotic and Dizygotic Twins. American Journal of Ophthalmology, 127, 158-163. http://dx.doi.org/10.1016/S0002-9394(98)00319-5

[4] Biio, G. and Corona, C. (2005) Ocular Refraction: Heritability and Genome-Wide Search for Eye Morphometry Traits in an Isolated Sardinian Population. Human Genetics, 116, 152-159. http://dx.doi.org/10.1007/s00439-004-1231-6

[5] Lyhne, N., Sjolie, A.K., Kyrik, K.O. and Green, O. (2001) The Importance of Genes and Environment on Ocular Refraction and Its Determinants: A Population Based Study among 20-45 Years Old Twins. British Journal of Ophthalmology, 85, 1470-1476.

[6] Young, T.L., Metlapally, R. and Shay, A.E. (2007) Complex Trait Genetics of Refractive Error. Archives of Ophthalmology, 125, 38-48.

[7] Mutti, D.O., Semina, E., Marazita, M., Cooper, M. and Murray, J.C. (2002) Genetic Loci for Pathologic Myopia Are Not Associated with Juvenile Myopia. American Journal of Medical Genetics, 112, 355-360. http://dx.doi.org/10.1002/ajmg.10683

[8] Lee, K.E., Klein, B.E. and Klein, R. (2001) Aggregation of Refractive Errors and 5-Year Changes in Refractive Errors among Families in the Beaver Dam Eye Study. Archives of Ophthalmology, 119, 1679-1685. http://dx.doi.org/10.1001/archopht.119.11.1679

[9] Czepita, D., Mojsa, A., Czepita, M. and Lachowicz, E. (2007) Role of Gender in the Occurrence of Refractive Errors. Annales Academiae Medicae Stetinensis, 53, 5-7. 
[10] Dirani, M., Chamberlain, M., Shekar, S.N., Islam, A.F., Garoufalis, P. and Chen, C.Y. (2006) Heritability of Refractive Error and Ocular Biometrics: The Genes in Myopia (GEM) Twin Study. Investigative Ophthalmology \& Visual Science, 47, 4756-4761. http://dx.doi.org/10.1167/iovs.06-0270

[11] Clementi, M., Angi, M., Forabosco, P., Di Gianantonio, E. and Tenconi, R. (1998) Inheritance of Astigmatism: Evidence for a Major Autosomal Dominant Locus. American Journal of Human Genetics, 63, 825-830. http://dx.doi.org/10.1086/302014

[12] Mohamed, D., Chamberlain, M., Shekar, S.N., Amirul, F.M., Garoufalis, P. and Chen, C.Y. (2006) Heritability of Refractive Error and Ocular Biometrics: The Genes in Myopia (GEM) Twin Study. IOVS, 47, 4756-4761.

[13] Foster, P.J. and Jiang, P.J. (2014) Epidemiology of Myopia. Eye, 28, 202-208. http://dx.doi.org/10.1038/eye.2013.280

[14] Goldschmidt, E. and Jacobsen, N. (2014) Genetic and Environmental Effects on Myopia Development and Progression. Eye, 28, 126-133. http://dx.doi.org/10.1038/eye.2013.254

[15] Ma, J.H., Shen, S.H., Zhang, G.W., Zhao, D.S., Xu, C., Pan, C.M., et al. (2010) Identification of a Locus for Autosomal Dominant High Myopia on Chromosome 5p13.3-p15.1 in a Chinese Family. Molecular Vision, 16, 2043-2054.

[16] Hysi, P.G., Young, T.L., Mackey, D.A., Andrew, T., Fernández-Medarde, A., Solouki, A.M., et al. (2010) A Genome-Wide Association Study for Myopia and Refractive Error Identifies a Susceptibility Locus at 15q25. Nature Genetics, 42, 902-905. http://dx.doi.org/10.1038/ng.664

[17] Solouki, A.M., Verhoeven, V.J., van Duijn, C.M., Verkerk, A.J., Ikram, M.K., Hysi, P.G., et al. (2010) A Genome-Wide Association Study Identifies a Susceptibility Locus for Refractive Errors and Myopia at 15q14. Nature Genetics, 42, 897-901. http://dx.doi.org/10.1038/ng.663

[18] Jones, L.A., Sinnott, L.T., Graham, N.D., Cotter, S.A., Kleinstein, R.N., Manny, R.E., et al. (2014) The Contributions of Near Work and Outdoor Activity to the Correlation between Siblings in the Collaborative Longitudinal Evaluation of Ethnicity and Refractive Error (CLEERE) Study. Investigative Ophthalmology \& Visual Science, 55, 6333-6339. http://dx.doi.org/10.1167/iovs.14-14640

[19] Huang, C.Y., Hou, C.H., Lin, K.K., Lee, J.S. and Yang, M.L. (2014) Relationship of Lifestyle and Body Stature Growth with the Development of Myopia and Axial Length Elongation in Taiwanese Elementary School Children. Indian Journal of Ophthalmology, 62, 865-869. http://dx.doi.org/10.4103/0301-4738.141047 
Submit or recommend next manuscript to SCIRP and we will provide best service for you:

Accepting pre-submission inquiries through Email, Facebook, LinkedIn, Twitter, etc. A wide selection of journals (inclusive of 9 subjects, more than 200 journals)

Providing 24-hour high-quality service

User-friendly online submission system

Fair and swift peer-review system

Efficient typesetting and proofreading procedure

Display of the result of downloads and visits, as well as the number of cited articles

Maximum dissemination of your research work

Submit your manuscript at: http://papersubmission.scirp.org/

Or contact ojgen@scirp.org 